\title{
ACUTE, NOT CHRONIC, EXPOSURE TO UNPREDICTABLE NOISE PERIODS AFFECTS SPLENIC LYMPHOCYTES AND PLASMA CORTICOSTERONE IN THE MOUSE
}

\author{
J. KUGLER, K.T. KALVERAM \\ Section: Psychobiology, Dept. of Psychology, Heinr.-Heine University Düsseldorf, \\ F.R.G. \\ and \\ K.W. LANGE \\ Institute of Psychiatry, Dept. of Neurology, London, United Kingdom
}

(Received November 20, 1989)

Keywords: acute stress, chronic stress, exposure to noise, corticosterone, spleen lymphocyte subsets

Over the last years, there has been a growing interest in the effects of stress on the immune system. The immunomodulative effects of acute stress are often documented (i.e., Teshima, Sogawa, Kiwara, Nagata, Ago, Nakagawa (1987)), whereas the influence of chronic stress is less clear. Monjan \& Collector (1977) report that acute exposure to noise stimuli decreases, chronic exposure increases immune function compared to the baseline level. The immunomodulative effects are accompanied by an increased corticosterone release after acute exposure to noise, and a decreased release after chronic exposure to noise.

In this study, we examined whether acute exposure to unpredictable noise periods differs from chronic exposure on its effect on splenic lymphocyte population and plasma corticosterone concentration.

Female mice of the C57/BL6 strain were subjected to a daily auditory stressor for one week or four weeks. The mice were 9 to 10 weeks old at the beginning of the experiment. They were housed in groups of five animals and maintained on a 12-hour light/12-hour dark cycle with free access to food and water. The mice of the experimental groups were exposed daily to broad band noise at about $100 \mathrm{~dB}$. Noise stimuli of 20 -second duration were presented on an average of every three minutes during a six-hour period around midnight. The intervals between the noise stimuli were randomly chosen (range 30 to 330 seconds). The control animals were exposed only to the normal animal room activity for either one or four weeks.

Percentages of $\mathrm{Thy}^{+}$-cells and of $\mathrm{Lyt}-1.2^{+}$cells present in the total number of splenic lymphocytes were determined using cytotoxic assay (Cedarlane, Hornby, Ontario, Canada). Plasma corticosterone was measured by radio-immuno-assay (Radioassay Systems Laboratories, Carson, California, USA). In order to rule out possible effects of the bleeding order on corticosterone level, only mice sacrified within four minutes after the first mouse in a cage were included in the analysis.

Exposure to unpredictable noise periods for a week clearly decreased both $\mathrm{Thy}^{+}$and Lyt-1.2+-lymphocytes, while after four weeks, no effects could be found (Table 
TABLE 1

Percentage of Thy ${ }^{+}$- and Lyt-1.2+ $2^{+}$-cells present in the total number of splenic lymphocytes and plasma corticosterone concentrations in mice after exposure to noise periods for I week, resp. 4 weeks and in control animals. Means and standard deviations are presented. $p$-values refer to the unpaired $t$-test.

\begin{tabular}{|c|c|c|c|}
\hline \multirow[b]{2}{*}{ groups } & \multicolumn{2}{|c|}{ Percentage of splenic } & \multirow{2}{*}{$\frac{\text { plasma corticosterone }}{(\mathrm{ng} / \mathrm{ml})}$} \\
\hline & $\mathrm{Thy}^{+}$-cells & Lyt-1.2+ $2^{+}$-cells & \\
\hline I week & $\begin{array}{l}31.4(3.3) \\
(n=10)\end{array}$ & $\begin{array}{l}12.6(2.1) \\
(n=10)\end{array}$ & $\begin{array}{c}83.6(19.6) \\
(n=6)\end{array}$ \\
\hline Control & $\begin{array}{c}39.0(6.4) \\
(n=5)\end{array}$ & $\begin{array}{l}16.0(1.9) \\
(n=5)\end{array}$ & $\begin{array}{c}47.3(5.1) \\
(n=3)\end{array}$ \\
\hline$t$-test & $p<.05$ & $p<.05$ & $p<.05$ \\
\hline 4 weeks & $\begin{array}{l}37.9(5.0) \\
(n=10)\end{array}$ & $\begin{array}{l}17.4(1.7) \\
(n=10)\end{array}$ & $\begin{array}{c}64.7(21.9) \\
(n=6)\end{array}$ \\
\hline Control & $\begin{array}{c}40.4(9.2) \\
(n=5)\end{array}$ & $\begin{array}{c}16.8(1.5) \\
(n=5)\end{array}$ & $\begin{array}{c}54.3(6.0) \\
(n=3)\end{array}$ \\
\hline$t$-test & $p=\mathrm{n} . \mathrm{s}$. & $p=$ n.s. & $p=\mathrm{n} . \mathrm{s}$ \\
\hline
\end{tabular}

1). A similar pattern could be found for plasma corticosterone. Only mice having had a short-term exposure to noise showed an increased corticosterone concentration which could not be found in mice after four week exposure to noises (Table 1).

Conclusions must be tempered because of small sample size and inclusion of only few parameters. However, the results indicate the importance of temporal parameters of the stress reaction. It can be concluded that acute exposure to unpredictable noise can be immunomodulative, whereas chronic exposure appears to have no effect on the percentage of splenic $\mathrm{Thy}^{+}$- and Lyt-1.2+-lymphocytes. Although the immunomodulative stress effects are associated with changes in corticosterone concentration the role of other mediators remains open.

\section{REFERENCES}

Monjan, A. A. \& Collector, M. I. (1977). Stress-induced modulation of the immune response. Science, 196, 307-308

Teshima, H., Sogawa, H., Kiwara, H., Nagata, S., Ago, Y. \& Nakagawa, T. (1987). Changes in populations of T-cell subsets due to stress. Annals of the New Yark Academy of Sciences, 496, 459-466 